\title{
PENGELOLAAN PERPUSTAKAAN KELILING DALAM UPAYA PENINGKATAN PELAYANAN PADA DINAS PERPUSTAKAAN DAN KEARSIPAN PROVINSI LAMPUNG
}

\author{
Lies Kumara Dewi ${ }^{1}$, Asmaria ${ }^{2}$, Eka Ubaya Taruna Rauf ${ }^{3}$ \\ Universitas Sang Bumi Ruwa Jurai \\ lieskumaradewi20@gmail.com
}

\begin{abstract}
Abstrak
Berbagai Alasan Sebagian Besar Masyarakat Yang Tidak Dapat Mengunjungi Perpustakaan dan Kearsipan Provinsi Lampung maka dalam upaya meningkatkan pelayanan disediakan layanan perpustakaan bergerak yang dikenal dengan sebutan Perpustakaan Keliling. Manfaat perpustakaan keliling bagi masyarakat antara lain dapat menyediakan bacaan-bacaan ringan tetapi bermutu. Koleksi yang tersedia berupa buku bacaan non fiksi, fiksi dan majalah. Namun masalah yang dihadapi oleh perpustakaan keliling tidak dapat melayani masyarakat yang haus akan informasi dengan koleksi yang terbatas, kurang profesionalnya pelayanan yang dilakukan oleh perpustakaan keliling. Adapun permasalahan dalam penelitian ini adalah bagaimana pengelolaan perpustakaan keliling dalam upaya peningkatan pelayanan pada Dinas Perpustakaan Dan Kearsipan Provinsi Lampung. Tujuan penelitian ini adalah mengetahui dan menganalisa pengelolaan perpustakaan keliling dan untuk mengetahui upaya peningkatan pelayanan pada Dinas Perpustakaan Dan Kearsipan Provinsi Lampung. Teknik pengumpulan data observasi, wawancara, dokumentasi. Analisis data yang digunakan analisis kualitatif.. Hasil penelitian dan pembahasan diketahui bahwa pengelolaan perpustakaan keliling pada Dinas Perpustakaan dan Kearsipan Provinsi Lampung masih terkendala beberapa masalah seperti terbatasnya koleksi buku yang ada, kurang profesionalnya pelayanan yang dilakukan oleh perpustakaan keliling disebabkan sumber daya manusianya yang masih kurang dan upaya Peningkatan Pelayanan pada Dinas Perpustakaan Dan Kearsipan Provinsi Lampung diketahui bahwa telah dilakukan berbagai upaya namun dalam beberapa hal masih ditemui seperti pegawai yang kurang mau mendengar keluhan masyarakat atau siswa (pengguna) perpustakaan keliling. Hal ini disebabkan terbatasnya pegawai yang ada.
\end{abstract}

Kata kunci : Pengelolaan Perpustakaan, Pelayanan

\begin{abstract}
For people who are unable to visit the Lampung Province Library and Archives for a variety of reasons, a mobile library service is known as the Mobile Library. The benefits of a mobile library for the community include providing light but quality reading. The collection is available in the form of non-fiction reading books, fiction and magazines. But the problems faced by mobile libraries cannot serve people who are hungry for information with limited collections, in providing very limited service time also due to lack of operational vehicles and lack of professional services performed by mobile libraries. The problem in this research is how to manage a mobile library in an effort to improve services at the Lampung Province Library and Archives Service. The purpose of this study is to find out and analyze the management of mobile libraries and to determine efforts to improve services at the Lampung Province Library and Archives Service. Data collection techniques are observation, interviews, documentation. Analysis of the data used qualitative analysis.The results of the study and discussion revealed that the management of the mobile library in the Lampung Province Library and Archives Service is still constrained by a number of problems such as the limited collection of books available, the lack of professional services carried out by the mobile library due to the lack of human resources and efforts to improve services at the Library Office and Lampung Province Archives is known that various efforts have been made but in some cases still encountered such as employees who are less willing to hear complaints from the public or students (users) of the mobile library. This is due to the limited staff available.
\end{abstract}

Keywords: Management of the Mobile Library, Improved Services 
Seminar Nasional Penelitian dan Pengabdian kepada Masyarakat

Universitas Sang Bumi Ruwa Jurai Tahun 2020

\section{PENDAHULUAN}

Perpustakaan saat ini telah dipergunakan sebagai salah satu pusat informasi, sumber ilmu pengetahuan, penelitian, rekreasi, pelestarian khasanah budaya bangsa, serta memberikan berbagai layanan jasa lainnya. Hal tersebut telah ada sejak dulu dan terus berproses secara alamiah menuju kepada suatu kondisi dan tingkat perbaikan yang signifikan meskipun belum memuaskan semua pihak. Nuzlianni Kadariyah, (2014:1)

Pada prinsipnya Perpustakaan memiliki tiga kegiatan, yaitu pertama, mengumpulkan (to collect) semua informasi yang sesuai dengan bidang kegiatan, misi organisasi, dan masyarakat yang dilayaninya. Kedua, melestarikan (to preserve), memelihara, dan merawat seluruh koleksi perpustakaan, agar tetap dalam keadaan baik, utuh, layak pakai, dan tidak lekas rusak, baik karena pemakaian maupun karena usianya. Ketiga, menyediakan dan menyajikan informasi untuk siap dipergunakan dan diberdayakan (to make availlable) seluruh koleksi yang dihimpun diperpustakaan untuk dipergunakan pemakainya. Sutarno NS, (2016:1)

Kegiatan-kegiatan perpustakaan terbagi dalam beberapa jenis perpustakaan, macammacam jenis perpustakaan ini yang membedakan tiap fungsi dan tujuan dari perpustakaan tersebut, salah satu dari jenis perpustakaan adalah Perpustakaan Umum. Perpustakaan Umum adalah perpustakaan yang seluruh atau sebagian dananya disediakan oleh masyarakat dan penggunannya tidak terbatas pada kelompok orang tertentu. Di samping itu lokasi Perpustakaan diupayakan cukup strategis dan mudah dicapai dengan kendaraan umum dari berbagai penjuru. Dengan berbagai kemudahan mendorong masyarakat untuk tertarik datang ke perpustakaan untuk memenuhi kebutuhannya dan memanfaatkannya secara mudah. Taslimah Yusuf, (2016:17)

Perpustakaan keliling merupakan bagian dari perpustakaan umum yang bertugas mendatangi pemakai dengan menggunakan kendaraan (darat maupun laut). Biasanya tugas ini merupakan bagian perluasan jasa dari sebuah perpustakaan umum untuk memungkinkan penduduk yang pemukimannya jauh dari perpustakaan agar dapat memanfaatkan jasa perpustakaan. Secara umum, perpustakaan keliling berfungsi sebagai perpustakaan umum yang melayani masyarakat yang tidak terjangkau oleh pelayanan perpustakaan umum. Nuzlianni Kadariyah, (2014:2)

Bagi masyarakat yang tidak mampu mengunjungi Perpustakaan dan Kearsipan Provinsi Lampung dengan berbagai alasannya, disediakan layanan perpustakaan bergerak yang dikenal dengan sebutan Perpustakaan Keliling. Manfaat perpustakaan keliling bagi masyarakat antara lain dapat menyediakan bacaan-bacaan ringan tetapi bermutu. Koleksi yang tersedia berupa buku bacaan non fiksi, fiksi dan majalah.

Perpustakaan keliling mendorong masyarakat agar gemar membaca untuk menambah wawasan berpikir, serta dapat pula menghibur anak-anak dan orang dewasa. Masyarakat yang tidak memiliki bahan bacaan umtuk keluarga dapat memanfaatkan layanan perpustakaan keliling ini. Minat baca dapat ditumbuhkan dan dikembangkan kembali, sehingga pada akhirnya dapat berkembang menjadi kebiasaan gemar membaca dan belajar seumur hidup. Nuzlianni Kadariyah, (2014:3)

Untuk menarik minat masyarakat terhadap perpustakaan, perpustakaan keliling harus mampu mengembangkan koleksi yang di milikinya. Fungsi perpustakaan keliling salah satunya adalah mempromosikan perpustakaan yang menjadi naungannya. Maka dari itu selain layanan yang baik, koleksi yang disediakan harus mampu menarik minat masyarakat untuk membaca bahan pustaka yang ada di perpustakaan keliling maupun di perpustakaan induk.

Salah satu masalah yang dihadapi oleh perpustakaan keliling adalah bagaimana mereka dapat melayani masyarakat yang haus akan informasi dengan koleksi terbatas dalam 
waktu layanan yang terbatas pula. Seperti yang datang tidak dapat meminjam buku dikarenakan terbatasnya buku yang ada kemudian masih ada buku yang dipinjam belum kembali sehingga masyarakat yang haus akan informasi tidak dapat terlayani dengan baik.

Pesatnya laju informasi, perpustakaan keliling harus berperan lebih giat lagi untuk menyebarkan informasi tersebut dalam berbagai bentuk, terutama informasi tersebut dalam bentuk yang berupa buku. Oleh karena itu pemilihan koleksi perpustakaan keliling haruslah benar-benar dilakukan dengan lebih profesional. Adapun masalah lain adalah seperti dalam memberikan waktu layanan sangat terbatas kepada masyarakat atau kesekolah sekolah dikarenakan kendaraan operasional sangat terbatas yang hanya terdiri dari 4 (empat) kendaraan, dimana 2 (dua) unit dimiliki arsip dan 2 (dua) unit dimiliki perpustakaan keliling yang harus memberikan pelayanan perpustakaan keliling ke 15 (lima belas) kabupaten/kota sehingga waktu yang digunakan sangat terbatas untuk operasionalnya.

Selain itu kurang profesionalnya pelayanan yang dilakukan oleh perpustakaan keliling yang disebabkan oleh sumber daya manusianya yang kurang dimana perpustakaan keliling hanya memiliki 5 (lima) orang pustakawan dan hanya memiliki sopir kendaraan hanya 1 (satu) orang, sehingga dinilai pelayanan perpustakaan keliling kurang profesional baik yang datang kesekolah-sekolah maupun ke tempat tempat masyarakat di setiap kabupaten/kota.

Perpustakaan dan Kearsipan Provinsi Lampung merupakan sebuah lembaga yang berada di bawah Perpustakaan Nasional, yang berfungsi membantu Perpustakaan Nasional dalam menjalankan visi, misi dan tujuan perpustakaan, yaitu memberikan pelayanan yang terbaik bagi masyarakat. Salah satu layanan yang ada di Perpustakaan dan Kearsipan Provinsi Lampung adalah Perpustakaan Keliling. Oleh karena itu, kami menyusun penelitian yang berjudul "Pengelolaan Perpustakaan Keliling Dalam Upaya Peningkatan Pelayanan Pada Dinas Perpustakaan Dan Kearsipan Provinsi Lampung".

\section{METODE PENELITIAN}

Penelitian ini dirancang atau desain melalui tahapan tahapan penelitian kualitatif, dimulai dari identifikasi masalah, perumusan masalah, tujuan dan kegunaan penelitian, mencari tinjauan pustaka sebagai dasar teori yang akan peneliti gunakan menentukan metode penelitian yang dapat digunakan meliputi : menentukan subjek dan sumber informasi, pengumpulan dan pengolahan data analisis data serta penetapan kesimpulan dimana proses mencari pemecahan masalah secara sistematis dengan menggunakan metode ilmiah serta aturaan-aturan yang berlaku.

Fokus penelitian peneliti pada masalah yang dihadapi oleh perpustakaan keliling adalah bagaimana mereka dapat melayani masyarakat yang haus akan informasi dengan koleksi terbatas dalam waktu layanan yang terbatas pula dan mengetahui sumber daya manusia apakah sudah profesional dalam memberikan pelayanan perpustakaan keliling. Dengan demikian pesatnya laju informasi, perpustakaan keliling harus berperan lebih giat lagi untuk menyebarkan informasi tersebut dalam berbagai bentuk, terutama informasi tersebut dalam bentuk yang berupa buku. Oleh karena itu pemilihan koleksi perpustakaan keliling haruslah benar-benar dilakukan dengan lebih profesional.

Sehingga penelitian ini difokuskan kepada Bagaimana Pengelolaan Perpustakaan Keliling Dalam Upaya Peningkatan Pelayanan Pada Dinas Perpustakaan Dan Kearsipan Provinsi Lampung, dengan indikator pengelolan perpustakaan : 1. Manusia (man), 2. Material (material), 3. Mesin (machine), 4. Metode (method), 5. Uang (money) dan 6. Pasar (markets) sedangkan indikator upaya peningkatan pelayanan dilakukan dengan 1. Senyum, 2. Sapa, 3. Ramah, 4. Dengar dan 5. Bantu. 
Seminar Nasional Penelitian dan Pengabdian kepada Masyarakat Universitas Sang Bumi Ruwa Jurai Tahun 2020

Lokasi penelitian adalah peneliti batasi pada hal hal yang berkaitan dengan penelitian saja yaitu Pengelolaan Perpustakaan Keliling Dalam Upaya Peningkatan Pelayanan Pada Dinas Perpustakaan Dan Kearsipan Provinsi Lampung.

Subyek dalam penelitian ini adalah pegawai Dinas Perpustakaan Dan Kearsipan Provinsi Lampung. Karena keterbatasan waktu, biaya dan tenaga maka yang dijadikan responden hanya beberapa orang saja yang menurut peneliti mengetahui dan memehami permaslahan yang akan di bahas. Maka hanya 3 (tiga) orang saja yang dijaikan responden. Sedangkan sumber informasi terdiri dari :

a. Kasie Layanan Perpustakaan Keliling (Alson, S.Sos)

b. Pustakawan (Liza Tri Handayani)

c. Staf Layanan Perpustakaan keliling (Agnes Sri Lestari)

Ketiga sumber informasi tersebut peneliti anggap mengetahui permasalahan yang akan peneliti ajukan. Teknik pengumpulan data yang penulis pergunakan dalam penyusunan penelitian ini adalah sebagai berikut :

a. Studi Kepustakaan, yaitu cara memperoleh data dengan cara membaca, mempelajari dan menganalisis berupa literature dari buku-buku, catatan-catatan, diktat-diktat, peraturan perundang-undangan, arsip-arsip dan dokumen-dokumen yang ada kaitannya dengan materi dan pembahasan penelitian ini.

b. Studi Lapangan, yaitu teknik pengumpulan data dengan secara langsung terjun kelapangan atau obyek penelitian yaitu Dinas Perpustakaan Dan Kearsipan Provinsi Lampung, yang terdiri atas ;

1. Observasi yaitu teknik pengumpulan data melalui pengamatan dan pencatatan masalah-masalah yang terjadi pada saat penelitian

2. Wawancara yaitu pengumpulan data dengan cara melakukan tanya jawab secara langsung

3. Dokumentasi yaitu pengumpulan data dengan cara menyalin atau mengkopi dokumen-dokumen serta catatan penting berupa data-data yang langsung berhubungan dengan penelitian ini.

Analisis yang dgunakan dalam penelitian ini untuk menganalisa adalah analisis kualitatif yaitu memberikan penjabaran terhadap hasil jawaban dari responden dengan uraian kalimat. Setelah dianalisis, selanjutnya diambil suatu kesimpulan untuk membuktikan permasalahan yang diajukan. Menurut Moleong, (2013:254) analisis kualitatif yaitu menguraikan kriteria-kriteria dan memberikan penjabaran terhadap hasil jawaban dari responden dengan uraian kalimat. Setelah dianalisis, selanjutnya diambil suatu kesimpulan.

\section{HASIL DAN PEMBAHASAN}

Dalam hasil dan pembahasan peneliti melakukan penelitian dan dikaitkan dengan teori teori serta penelitian yang terdahulu sehingga diketahui hasil penelitian yang diharapkan peneliti. Untuk mencapai tujuan yang telah ditetapkan, seorang manajer membutuhkan sarana pengelolaan yang disebut dengan unsur unsur pengelolaan. Menurut pendapat yang dikemukakan oleh Manullang sebagaimana dikutip oleh Mastini, (2013:87) tentang unsur pengelolan terdiri atas man, material, machine, method, money dan markets, setiap unsurunsur tersebut memiliki penjelasan dan peranan bagi suatu pengelolaan agar untuk mengetahui bahwa pengelolaan memiliki unsur-unsur perlu dimanfaatkan unsur-unsur pengelolaan tersebut.

Bahwa kurang profesionalnya pelayanan yang dilakukan oleh perpustakaan keliling yang disebabkan oleh sumber daya manusianya yang kurang dimana perpustakaan keliling hanya memiliki 5 (lima) orang pustakawan dan hanya memiliki sopir kendaraan hanya 1 
Seminar Nasional Penelitian dan Pengabdian kepada Masyarakat Universitas Sang Bumi Ruwa Jurai Tahun 2020

(satu) orang, sehingga dinilai pelayanan perpustakaan keliling kurang profesional baik yang datang kesekolah-sekolah maupun ke tempat tempat masyarakat di setiap kabupaten/kota.

Hal ini sesuai dengan pendapat Mastini, (2013:87) Man atau manusia ataupun juga sering diistilahkan dengan sumber daya manusia dalam dunia manajemen merupakan faktor yang sangat penting dan menentukan. Manusia yang merancang tujuan, menetapkan tujuan dan manusia jugalah yang nantinya akan menjalankan proses dalam mencapai tujuan yang ditetapkan tersebut.Sudah jelas, tanpa adanya manusia maka tidak akan pernah ada proses kerja karena manusia pada dasarnya adalah mahluk kerja.

Berdasarkan hasil penelitian dan pembahasan serta dikaitkan dengan teori maka diketahui bahwa Man atau manusia ataupun juga sering diistilahkan dengan sumber daya manusia dalam dunia pengelolaan merupakan faktor yang sangat penting dan menentukan, jika sumber daya manusia kurang memadai maka akan dipastikan kurang profesionalnya pelayanan yang dilakukan oleh perpustakaan keliling yang hanya memiliki 5 (lima) orang pustakawan dan hanya memiliki sopir kendaraan hanya 1 (satu) orang.

Material dalam mengelola perpustakaan keliling sudah sesuai dengan standar operasional prosedur yang ditetapkan diantaranya setiap mobil dilengkapi buku buku yang terbaru baik hukum, ekonomi, budaya, sejarah dan pembangunan administrasi, adanya fasilitas wifi (internet) dan pustakawan yang tanggap serta adanya ruang konsultasi dan terjemahan literatur. Namun dalam memberikan waktu layanan sangat terbatas kepada masyarakat atau kesekolah sekolah dikarenakan kendaraan operasional sangat terbatas yang hanya terdiri dari 5 (lima) kendaraan, dimana 2 (dua) unit dimiliki arsip dan 3 (tiga) unit dimiliki perpustakaan keliling yang harus memberikan pelayanan perpustakaan keliling ke 15 (lima belas) kabupaten/kota sehingga waktu yang digunakan sangat terbatas untuk operasionalnya.

Dimana menurut Mastini (2013:87) dalam proses pelaksanaan kegiatan, manusia menggunakan material atau bahan-bahan. Oleh karna itu, material dianggap pula sebagai alat atau sarana manajemen untuk mencapai tujuan. Sehingga peneliti berkesimpulan bahwa berdasarkan penelitian dan teori tersebut maka antara teori dan praktek sangat berbeda dikarenakan material sudah sesuai dengan standar operasional prosedur tetapi kenyataannya kendaraan operasional sangat terbatas. Dalam pengelolaannya material yang telah disiapkan dalam setiap mobil anatara lain dilengkapi buku buku yang terbaru baik hukum, ekonomi, budaya, sejarah dan pembangunan administrasi, adanya fasilitas wifi dan pustakawan yang tanggap. Setiap mobil telah menggunakan sistem camera pengawas, pencarian digital buku dengan menggunakan komputer data base, pelayanan audio visual, pelayanan internet serta fasilitas ruang terjemahan dan ruang konsultasi di dalam mobil.

Bahwa teknologi yang digunakan pengelolaan perpustakaan keliling adalah setiap mobil telah menggunakan sistem camera pengawas, pencarian digital buku dengan menggunakan komputer data base, pelayanan audio visual, pelayanan internet (penelusuran buku dengan menggunakan jaringan) serta fasilitas ruang terjemahan dan ruang konsultasi di dalam mobil. Hal ini sesuai dengan teori Mastini, (2013:87) yang menyebutkan dalam kemajuan teknologi, manusia bukan lagi sebagai pembantu mesin seperti pada masa lalu sebelum Revolusi Industri terjadi. Bahkan, sebaliknya mesin telah berubah kedudukannya menjadi pembantu manusia. Hasil penelitian dan pembahasan serta teori yang digunakan maka peneliti berkesimpulan bahwa dalam pengelolaan perpustakaan keliling Dinas Perpustakaan dan Kearsipan Provinsi Lampung telah melakukan terobosan seperti sistem camera pengawas, pencarian digital buku dengan menggunakan komputer data base, pelayanan audio visual, pelayanan internet.

Metode yang digunakan pengelolaan perpustakaan keliling dengan medote Inliss Lite. Dimana metode ini menitik beratkan kepada layanan yang baik. Layanan yang berorientasi 
pada pemustaka. Dalam hal ini dapat diartikan bahwa layanan yang baik adalah layanan yang berorientasi pada kebutuhan yang diinginkan/diharapkan pemustaka, tepat mengenai sasaran sesuai dengan tuntutan para pemustaka. Oleh karena itu, dalam memenuhi kebutuhan informasi pada pemustaka, penerapan konsep layanan yang baik merupakan sesuatu yang harus diterapkan. Dalam hasil penelitian dan pembahasan peneliti juga mengkaitkan dengan teori Mastini, (2013:87) yang menyebutkan bahwa untuk melakukan kegiatan secara guna dan berhasil guna, manusia dihadapkan kepada berbagai alternatif metode dengan cara menjalankan pekerjaan tersebut sehingga cara yang dilakukannya dapat menjadi sarana atau alat pengelolaan untuk mencapai tujuan.

Sehingga diperoleh hasil penelitian dan pembahasan sesuai dengan teori yang peneliti gunakan dimana Pengelolaan Perpustakaan Keliling Dalam Upaya Peningkatan Pelayanan pada Dinas Perpustakaan dan Kearsipan Provinsi Lampung sudah menggunakan metode Inliss Lite. Dimana metode ini menitik beratkan kepada layanan yang baik. Hasil penelitian diketahui bahwa proses pengelolaan sedikit banyak dipengaruhi oleh pengelolaan keuangan (money), oleh sebab itu pengelolaan keuangan harus benar benar dianggarkan sesuai dengan peruntukkannya demi kelancaran kegiatan yang telah disusun. Anggaran untuk mencapai tujuan perpustakaan. Karena perpustakaan sekolah sebagai sub sistem dari sebuah organisasi, dalam hal ini yaitu sekolah, tentunya tujuan perpustakaan sekolah harus terlebih dahulu didefinisikan secara jelas. Sehingga dapat disimpulkan peneliti bahwa keuangan ataupun anggaran, seringkali bersinggungan dengan kejahatan terhadap keuangan dan anggaran. Apalagi Perpustakaan dalam sebuah institusi pemerintahan ataupun swastas. Terlebih lagi di perguruan tinggi, yang notabenenya anggaran perpustakaan terbilang besar. Namun kenyataannya uang sebagai sarana pengelolaan harus digunakan sedimikian rupa agar tujuan yang diinginkan tercapai dan sesuai dengan yang diharapkan.

Dalam melakukan pasar (markets) pengelolaan perpustakaan keliling membuat program kerja disamping itu juga menambah koleksi yang menarik sehingga semakin menarik minat pemustaka perpustakaan keliling, maka perlu dilakukan pengembangan koleksi yang diperlukan untuk mengetahui koleksi apa saja yang diminati pemustaka. Pengembangan koleksi diperlukan untuk memperbaharui koleksi perpustakaan keliling, selain itu untuk mengetahui koleksi yang sudah tidak diminati pemustaka.

Diketahui bahwa waktu yang diberikan Perpustakaan Keliling Dalam Upaya Peningkatan Pelayanan Pada Dinas Perpustakaan Dan Kearsipan Provinsi Lampung kepada masyarakat dan sekolah sekolah dilakukan dengan baik dan ideal yaitu mulai pukul 09.0014.00 WIB. Mengingat layanan perpustakaan keliling bersifat demokratis yang berarti melayani semua lapisan masyarakat, maka waktu layanan perlu diatur sebaik-baiknya sehingga dapat melayani semua pihak yang membutuhkan informasi dan jasa perpustakaan keliling. Secara ideal waktu layanan perpustakaan keliling pada Dinas Perpustakaan dan Kearsipan Provinsi Lampung yang dilakukan dari pukul 09.00 - 14.00. Berdasarkan hasil penelitian dan pembahasan serta dikaitkan dengan teori Darmono, (2015:72) bahwa pemilihan koleksi perpustakaan keliling haruslah benar-benar dilakukan dengan lebih profesional. Namun permasalahan muncul yaitu masalah yang dihadapi oleh perpustakaan keliling tidak dapat melayani masyarakat yang haus akan informasi dengan koleksi terbatas dan waktu layanan sangat terbatas dikarenakan kendaraan operasional sangat terbatas yang hanya terdiri dari 5 (lima) kendaraan, dimana 2 (dua) unit dimiliki arsip dan 3 (tiga) unit dimiliki perpustakaan keliling yang harus memberikan pelayanan perpustakaan keliling ke 15 (lima belas) kabupaten/kota sehingga waktu yang digunakan sangat terbatas untuk operasionalnya.

Berdasarkan hasil penelitian dan dilakukan pembahasan diketahui bahwa kurang profesionalnya pelayanan yang dilakukan oleh perpustakaan keliling disebabkan oleh sumber 
Seminar Nasional Penelitian dan Pengabdian kepada Masyarakat Universitas Sang Bumi Ruwa Jurai Tahun 2020

daya manusianya yang kurang dimana perpustakaan keliling hanya memiliki 5 (lima) orang pustakawan dan hanya memiliki sopir kendaraan hanya 1 (satu) orang, sehingga dinilai pelayanan perpustakaan keliling kurang profesional baik yang datang kesekolah-sekolah maupun ke tempat tempat masyarakat di setiap kabupaten/kota. Sehingga peneliti berkesimpulan setelah dilakukan pembahasan dan dikaitkan dengan teori bahwa untuk peningkatan pelayanan perlu dilakukan penambahan pustakawan dan tenaga pengemudi yang sesuai dengan kompetensinya.

Hal ini sesuai dengan teori M.Nur Rianto Al Arif, (2012), yang menyatakan bahwa pegawai perpustaaan keliling dalam memberikan pelayanan sudah sesuai dengan yang dijanjikan yaitu memberikan senyum. Berdasarkan penelitian dan pembahasan diketahui bahwa pegawai perpustakaan keliling dalam melayani masyarakat dilakukan dengan memberikan senyum kepada penguna dengan sebaik-baiknya sehingga selalu dapat memenuhi segala permintaan pengunjung akan bahan pustaka, berarti fungsi layanan dalam memenuhi kebutuhan pengunjung perpustakaan keliling akan memenuhi fungsi perpustakaan keliling sebagai pusat edukasi, informasi, rekreasi dan referensi bagi masyarakat yang dikunjunginya walaupun dengan koleksi terbatas.

Layanan perpustakaan keliling pada dasarnya bersifat terbuka dan demokratis, karena perpustakaan keliling melayani semua lapisan masyarakat tanpa membedakan status sosial, budaya, ekonomi, pendidikan, kepercayaan maupun status-status lainnya. Semua warga masyarakat tanpa mengenal batas usia, bebas memanfaatkan layanan jasa perpustakaan keliling. Hal ini sesuai dengan teori yang diutarakan oleh M.Nur Rianto Al Arif, (2012) yaitu bahwa senyum adalah suatu upaya peningkatan pelayanan yang diberikan kepada masyarakat, dengan penyampaian informasi yang jelas. Sehingga peneliti berkesimpulan bahwa upaya peningkatan pelayanan melalui menyapa yang dilakukan pustakawan dan staf layanan perpustakaan keliling dapat meningkatkan pelayanan kepada semua lapisan masyarakat tanpa membedakan status sosial, budaya, ekonomi, pendidikan, kepercayaan maupun status-status lainnya.

Berdasarkan hasil penelitian diketahui bahwa keramahan pelayanan yang diberikan kepada masyarakat sudah baik walaupun masih terdapat kekurangan, namun dengan keramahan pelayanan yang diberikan pemustaka cukup memberikan kepuasan kepada masyarakat dengan fasilitas yang sudah ada pada perpustakaan keliling, misalnya kegiatan menonton film, perpustakaan keliling menyediakan berbagai macam koleksi film salah satunya tentang kisah nabi atau tentang pengetahuan umum, selain koleksi film dan buku, koleksi permainan juga menjadi salah satu daya tarik masyarakat dan anak-anak.

Bahwa terkait mendengar pegawai harus memiliki sikap mendengar dan menunjukkan bahwa ia mendengarkan keluhannya pengguna perpustakaan keliling, serta lebih mengutamakan kepentingan pengguna atau masyarakat. Dengan bersikap mendengar maka pengguna akan merasa dihargai dan diterima dalam keluhnnya. Sikap mendengar pegawai pustakawan perlu dibiasakan dalam kegiatan perpustakaan keliling agar menjadi karakter pribadi yang lebih baik lagi, dan sikap mendengar ini juga harus dibiasakan sehingga pegawai bisa bersikap mendengar kepada pengguna perpustakaan keliling.

Hasil penelitian diketahui bahwa Pengelolaan Perpustakaan Keliling Dalam Upaya Peningkatan Pelayanan pada Dinas Perpustakan dan Kearsipan Provinsi Lampung dalam memberikan pelayan membantu dan bersifat individual atau pribadi yang diberikan kepada para masyarakat dengan berupaya memahami keinginan masyarakat atau pembaca. Hal ini sesuai dengan teori M.Nur Rianto Al Arif, (2012) yang menyatakan membantu yaitu memahami keinginan pengguna perpustakaan keliling, segeralah membantunya. Berikan 
solusi terbaik dan tercepat agar tercapai kepuasan maksimal bagi pengguna. Sebaik apapun solusi yang diberikan bila tidak dilakukan secara cepat akan mengurangi nilainya.

Meskipun dalam praktek nyatanya Layanan Perpustakaan Keliling masih banyak sekali dijumpai berbagai hambatan, bukan berarti tidak ada pemecahan atau solusinya. Berikut ini pemecahan hambatan tersebut, diantaranya:

1. Masalah yang dihadapi oleh perpustakaan keliling tidak dapat melayani masyarakat yang haus akan informasi dengan koleksi terbatas.

Solusi :

Penambahan jumlah koleksi secara berkala sebelumnya setiap satu tahun sekali bisa di percepat setiap enam bulan sekali ditambah. Sehingga informasi bisa terus berkembang tidak statis dan penguna juga tidak bosan karena adanya koleksi yang baru.

2. Dalam memberikan waktu layanan sangat terbatas

Solusi :

Dengan jumlah armada Operasional Perpustakaan Keliling yang sangat terbatas, maka diperlukan suatu sistem yang selektif guna memilih daerah mana saja yang jadi prioritas dan pembuatan jadwal Layanan Perpustakaan Keliling yang merata, sehingga tidak terjadi ketimpangan daerah yang dilayani.

3. Kurang profesionalnya pelayanan yang dilakukan oleh perpustakaan keliling.

Solusi :

Pengelolaan perpustakaan keliling perlu ditambah jumlahnya sehingga kesekolah bisa ditingkatkan lagi, karena sebenarnya sudah ada perpustakaan setiap sekolah meskipun tidak semua. Tetapi peran dari guru dalam mengelola maupun menumbuhkan minat baca siswa sangat lemah, menyebabkan lambat laun perpustakaan tersebut semakin terlupakan. menyebabkan peran dari Layanan Perpustakaan Keliling saja. Padahal tidak setiap hari bisa dilayani. Dan untuk sekolah yang belum mempunyai sarana perpustakaan bisa bekerja sama dengan pihak terkait misalnya Perpustakaan Daerah yang bisa meminjamkan sejumlah buku untuk pengadaan koleksi perpustakaan.

Dan :

Pelatihan terhadap petugas perpustakaan keliling harus sering dilakukan agar petugas tersebut selalu mempunyai semangat dalam memberikan layanan, sehingga pengunjung merasa puas.

berikut :

Upaya yang dilakukan perpustakaan keliling dalam peningkatan pelayanan sebagai

1. Pengembangan dan penambahan koleksi yang dilakukan perpustakaan keliling dalam peningkatan pelayanan sering menghadapi kendala, terkadang koleksi yang ingin dikembangkan perpustakaan keliling tidak disetujui oleh bagian pengadaan Dinas Perpustakaan Dan Kearsipan Provinsi Lampung. Disisi lain pemustaka banyak sekali yang memberi saran untuk mengembangkan dan menambah koleksi perpustakaan keliling, misalnya pemustaka yang memang memanfaatkan perpustakaan keliling untuk sekedar membaca atau mencari buku yang dibutuhkan tidak ada pada tempatnya, atau terkadang pemustaka yang sering berkunjung ke perpustakaan keliling melihat koleksinya tidak ada perubahan. Karena koleksi yang masih belum ada perubahan, maka dari itu pemustaka sering komplain ke petugas tentang koleksi yang ada di perpustakaan keliling, dan dari kendala ini petugas menerima saran judul buku apa saja yang diperlukan pemustaka. Upaya yang dilakukan pengembangan koleksi hanya dilakukan setahun sekali dan tidak semua judul buku akan diadakan tetapi petugas selalu menerima saran dari pemustaka perpustakaan keliling, untuk kemajuan perpustakaan keliling di masa depan.

Upaya yang dilakukan oleh petugas layanan perpustakaan keliling sudah mampu mengatasi kendala yang dihadapi perpustakaan keliling meskipun tidak semua kendala 
Seminar Nasional Penelitian dan Pengabdian kepada Masyarakat

Universitas Sang Bumi Ruwa Jurai Tahun 2020

bisa diselesaikan tapi petugas sudah berupaya untuk memperbaiki layanan perpustakaan keliling dengan memberikan senyum, sapa, keramahan, mendengar dan membantu, dengan upaya dan kerjasama yang dilakukan oleh petugas perpustakaan keliling dan staf bagian layanan menjadikan masalah-masalah yang terjadi sebagai bahan evaluasi untuk perbaikan perpustakaan keliling di masa yang akan datang.

2. Upaya menambah armada kendaraan guna operasional kegiatan ke daerah daerah dengan jumlah armada Operasional yang disesuaikan dengan kegiatan Perpustakaan Keliling yang sangat terbatas tersebut, agar dalam memberikan waktu layanan dapat memuaskan pembaca dan masyarakat yang membutuhkan literatur.

3. Upaya mengatasi kendala kurang profesionalnya pelayanan yang dilakukan oleh perpustakaan keliling yaitu dengan menambah jumlah pustakawan dan staf layanan perpustakaan keliling dan memberikan pelatihan terhadap petugas perpustakaan keliling harus sering dilakukan agar petugas tersebut selalu mempunyai semangat dalam memberikan layanan seperti senyum, sapa, keramahan, mendengar dan membantu, sehingga pengunjung merasa puas serta sebelum memulai kunjungan petugas perpustakaan keliling mengadakan kegiatan observasi setelah itu baru melakukan perjanjian dengan bagian sekolah yang ingin dikunjungi agar tidak terjadi kesamaan jadwal kegiatan sekolah dan kegiatan perpustakaan keliling sehingga terlihat profesional pelayanan yang memang diharapkan masyarakat atau pihak sekolah sekolah yang dikunjungi dan didatangi oleh Pengelolaan Perpustakaan Keliling Dalam Upaya Peningkatan Pelayanan pada Dinas Perpustakaan dan Kearsipan Provinsi Lampung.

\section{KESIMPULAN}

1. Pengelolaan perpustakaan keliling pada Dinas Perpustakaan dan Kearsipan Provinsi Lampung masih terkendala beberapa masalah seperti terbatasnya koleksi buku yang ada, kurang profesionalnya pelayanan yang dilakukan oleh perpustakaan keliling disebabkan sumber daya manusianya yang masih kurang

2. Upaya Peningkatan Pelayanan pada Dinas Perpustakaan Dan Kearsipan Provinsi Lampung berdasarkan hasil penelitian diketahui bahwa telah dilakukan berbagai upaya seperti telah diluncurkannya program lampung berjaya dimana program tersebut mengenai gemar membaca, namun dalam beberapa hal masih ditemui seperti pegawai yang kurang mau mendengar keluhan masyarakat atau siswa (pengguna) perpustakaan keliling. Hal ini disebabkan terbatasnya pegawai.

\section{UCAPAN TERIMA KASIH}

Diucapkan terima kasih kepada segenap pihak pihak yang terkait dalam terselesaikannya penelitian ini, namun tiada suatu karya besar tanpa berani memulainya dari sesuatu yang kecil oleh karena itu kritik dan saran yang bersifat membangun sangat diharapkan. Semoga amal baik yang Bapak, Ibu dan rekan rekan berikan mendapat pahala yang setimpal dari Allah SWT, Amin

\section{DAFTAR PUSTAKA}

Saleh. (2015). Manajemen Administrasi Perguruan Tinggi. Jakarta

Boediono. (2013). Pelayanan Prima Perpajakan. PT. Rineka Cipta: Jakarta

Darmono, (2015) Manajemen dan Tata Kerja Administrasi Kearsipan. Jakarta Grasindo 
Seminar Nasional Penelitian dan Pengabdian kepada Masyarakat Universitas Sang Bumi Ruwa Jurai Tahun 2020

Dendy Sugono. (2018). Kamus Besar Bahasa Indonesia Edisi Ke- 4 Jakarta: Gramedia

Dwiyanto Indihono (2016). Reformasi Birokrasi Yogyakarta: Penerbit Gaya Media

Lupioadi (2016). Membangkitkan Budaya Kewirausahaan Jakarta Salemba Empat

Manullang sebagaimana dikutip oleh Mastini (2013). Dasar-Dasar Manajemen, edisi revisi, cetakan ketujuh. Yogyakarta Ghalia Indonesia

M.Nur Rianto Al Arif. (2012). Dasar-dasar Pemasaran, Bandung: Alfabeta.

Mastini Hardjoprakoso (2012) Panduan Penyelenggaraan Perpustakaan Umum Jakarta : Perpustakaan Nasional RI

Moleong (2013). Metode Penelitian Kuantitatif Kualitatif Dan $R \&$ D. Bandung : Alfabeta Nuzlianni Kadariyah (2014). Pengelolaan Perpustakaan Keliling Di Perpustakaan Daerah Tangerang Selatan. Program Studi Ilmu Perpustakaan Fakultas Adab Dan Humaniora Universitas Islam Negeri Syarif Hidayatullah Jakarta

Sugiyono (2014). Metode Penelitian Kuantitatif Kualitatif dan R\&D. Bandung : Alfabeta.

Sukarman (2010). Pedoman Umum Penyelenggaraan Perpustakaan Umum , (Jakarta: Perpustakaan Nasional RI)

Sulistyo Basuki. (2011). Pengantar Ilmu Perpustakaan dan Administrasi. Jakarta : Gramedia Pustaka

Sutarno NS. (2016). Perpustakaan dan Masyarakat, Sagung Seto, Jakarta

Supriyanto (2014). Perpustakaan Dan Pustakawan. Jakarta : Ikatan Pustakawan Indonesia DKI Jakarta

Talizidhuhu Ndraha (2017). Kybernology (Ilmu Pemerintahan Baru), Jakarta: PT. Rineka Cipta

Taslimah Yusuf (2016). Manajemen Perpustakaan Umum Universitas Terbuka, Jakarta

Undang-Undang Republik Indonesia Nomor 43 Tahun 2007 Tentang Perpustakaan. Jakarta : Perpustakaan Nasional RI, 2007. 